\section{Coal liquefaction}

\section{Trial by post}

The future of the United Kingdom's only serious programme in coal liquefaction technology has been placed in doubt by a tense exchange of letters between the chairman of the National Coal Board (NCB), Sir Derek Ezra, and the Chief Scientist of the Department of Energy, Dr Tony Challis.

NCB has been waiting a year for a reply from the department about its proposal to build a 25 -tonne-a-day pilot liquefaction plant at the Point of Ayr in North Wales, using two alternative technologies and costing $£ 65$ million to the government. These plans have become part of an agreement between the department, NCB and the National Union of Miners.

But, claims Dr Challis in his letter, on the assumption that oil conservation measures take full effect, and that sufficient oil-fired boilers are converted to coal-burning, "it seems likely that the United Kingdom can maintain net self-sufficiency in transport fuels and chemical feedstocks well into the next century", and thus that the United Kingdom does not need to develop an indigenous coal liquefaction technology, particularly when British coal is expensive (relative to American and Australian coal) and "bearing in mind the formidable level of international effort already applied in this field".

Dr Challis admits that NCB technology could be 30 per cent more energy-efficient than rival processes - after all, his own staff collaborated in the calculation - but says this is not enough to counter the 6-year lead-time in scale enjoyed by, say, the 200-tonne-a-day Exxon Donor Solvent plant at Baytown, United States. Dr Challis's letter, was written just after his return from a visit to this plant, so it seems Exxon have successfully "sold" him their technology.

$\mathrm{He}$ also argues that a 1-tonne-a-day plant followed by a 200 -tonne-a-day plant would make better sense than the intermediate 25-tonne-a-day liquefier planned by NCB. Also, according to Dr Challis, who was a chemical engineer himself, NCB has "lacked adequate strength or perspective in the translation from chemistry to chemical engineering", and the translation has been done in too much of a hurry.

Sir Derek Ezra, in reply to Dr Challis, chides him for the department's late change of heart - and expresses surprise at Challis's optimistic view of Britain's oil supply, "more optimistic than the official view of the Department of Energy". And it is not at all clear, says Sir Derek, that countries with cheap surplus coal would be prepared to supply it cheaply in the future, when coal is in greater demand - so the cost of our own coal is not relevant.

Sir Derek believes that liquefaction technology will be needed in the United
Kingdom in the 1990s, and that NCB technology presents "a sufficient advance over the technologies being developed in the United States and Germany to merit support'".

The American technology - and a similar plant under construction at Bottrop in West Germany - is, in fact, based largely on the wartime German technology (also employed at SASOL in South Africa) which splits the coal into monocarbon compounds, resynthesizing them to make light liquids. The resulting liquids possess only 30 per cent or so of the chemical energy of the original coal, whereas the $\mathrm{NCB}$ process which takes coal directly to light liquids, can promise $60-70$ per cent efficiency.

British Petroleum is prepared to back the project, while NCB itself will contribute $£ 18$ million, and the project would receive about $£ 12$ million from the energy research fund of the European Community, if only the Department of Energy would give it their approval. Moreover, potential buyers of the technology in Canada and Australia will only show serious interest when a pilot plant is built.

However, despite Dr Challis's views, the

\section{From rank weeds to riches}

\section{New Delhi}

Workers in India have found a way of converting water hyacinth (Eichornia crassipes) into paper, and in so doing may have solved one of the Third World's major problems. This free-floating and fast-growing weed is not only a menace to navigation and hydroelectric power generation in affected countries, but also offers a breeding ground for pests and insects. So far, all efforts have been directed at eradication of the weed. Now, the Regional Research Laboratory (RRL) in Hyderabad, controlled by the Council of Scientific and Industrial Research, is making writing paper, posters, even invitation cards, using the leaves of water hyacinth collected from the city's lakes. Because the raw material is virtually free the paper is cheap and may save some of the trees cut down to feed the paper industry.

The technology for converting the weed into paper was developed through an international project initiated in 1978 by the London-based Commonwealth Science Council. The council, which identified water hyacinth as a major problem in the Third World, asked India to coordinate a project on the control and utilization of the weed and helped the collaborating countries to obtain a grant of $\$ 200,000$ from the United Nations Development Programme. While Sri Lanka, Bangladesh and Malaysia worked on biological control and biogas production, India chose to investigate the use of the weed in paper making. And, when scientists from the collaborating department has not yet made a formal decision about the plant. The next step should be a meeting shortly between the minister for coal John Moore, Sir Derek Ezra, Dr Challis and the research director of NCB, Dr Joe Gibson. If they can reach agreement, their recommendation will then be forwarded to the Secretary of State for Energy for a decision.

Meanwhile, in the United States President Keagan has appointed an Oklahoma businessman, $\mathrm{Mr}$ Edward $\mathrm{E}$. Noble, to be chairman of the Synthetic Fuels Corporation which will oversee synfuel development in the United States. Mr Noble is reported to be uneasy at the large numbers of US technologies aimed at producing gas, and uncertain that the mandated targets of 0.5 million barrels a day (oil equivalent) of synfuel by 1987 and 2 million by 1992 can be reached.

In London, the director of the International Energy Agency said that given uncertainties over nuclear and renewable sources of energy, coal was poised to become the "single most important energy contribution to the future of modern society"'.

Robert Walgate

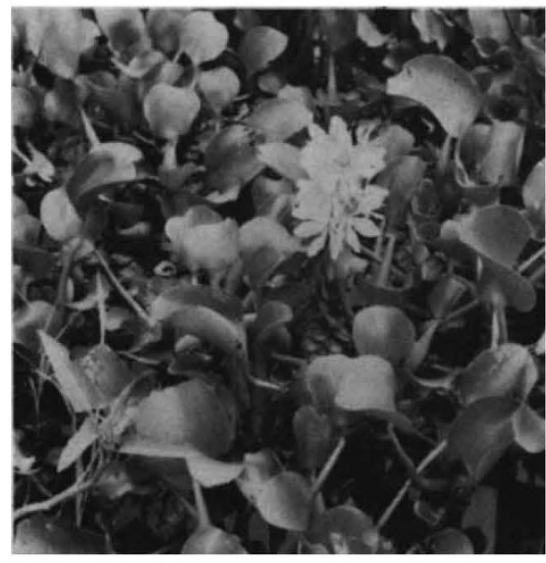

Water hyacinth - paper power?

countries recently visited the RRL pilot plant, they were so impressed that they now plan to set up similar plants in their own countries.

The emergence of water hyacinth as a source of raw material for the paper industry should have great impact in India, where at least four million hectares of water surface are covered with the weed. The average yield of water hyacinth is 50 tonnes per hectare, giving India 200 million tonnes of non-forest raw material for paper. If even half of this is used, and assuming a 10 per cent conversion efficiency, the country can provide 10 million tonnes of paper from the weed. The new paper-making factories can be set up wherever water hyacinth grows and the process is such that the paper can be hand-produced by unskilled workers.

K.S. Jayaraman 